\title{
Peningkatan Aktivitas dan Hasil Belajar Fisika Matematika 1 dengan Metode Brainstorming dan Tutor Teman Sebaya
}

\author{
Siska Desy Fatmaryanti \\ Program Studi Pendidikan Fisika Universitas Muhammadiyah Purworejo \\ Surat-e: sd_fatmaryanti@yahoo.com \\ Penelitian ini bertujuan untuk meningkatkan aktivitas dan hasil belajar Fisika Matematika I \\ dengan metode brainstroming dan tutor teman sebaya. Subyek penelitian adalah mahasiswa prodi \\ Pendidikan Fisika UM Purworejo semester 3 tahun akademik 2012/2013. Penelitian ini \\ dilakukan di prodi Pendidikan Fisika UM Purworejo dengan desain penelitian tindakan kelas dua \\ siklus. Instrumen yang digunakan adalah instrumen aktivitas belajar dan instrumen prestasi untuk \\ mengukur hasil belajar. Hasil penelitian menunjukkan bahwa penggunaan 2 metode ini yaitu \\ brainstorming dan tutor teman sebaya dapat meningkatkan aktivitas dan prestasi belajar. Hal itu \\ terlihat dari $6 \mathrm{I}$ mahasiswa yang diberi tindakan, terdapat peningkatan aktivitas belajar yakni dari \\ 37,54\% menjadi 5I\% dan peningkatan hasil belajar yakni dari nilai rata-rata kelas 58,7 (C-) \\ menjadi $65,4(\mathrm{~B}-)$
}

Kata kunci: aktivitas belajar, hasil belajar, brainstroming, tutor teman sebaya

\section{Pendahuluan}

Fisika Matematika merupakan mata kuliah yang menuntut mahasiswa memiliki kemampuan merumuskan berbagai persoalan fisika ke dalam pernyataan matematis dan menyelesaikannya secara analitis. Mata kuliah ini merupakan salah satu perkuliahan yang memiliki tingkat kesulitan yang tinggi di kalangan mahasiswa Pendidikan Fisika Universitas Muhammadiyah Purworejo. Indikatornya adalah dari hasil ujian semester Fisika Matematika I dan 2 pada tahun 20I0/20II dan 201I/20II sekitar $60 \%$ mahasiswa mendapat nilai rata-rata $60(\mathrm{C})$.

Berdasarkan pengamatan peneliti selama mengampu mata kuliah ini penyebab utama adalah rendahnya aktivitas belajar mahasiswa, baik dalam mengajukan pertanyaan, mengemukakan pendapat, mengerjakan tugas yang diberikan oleh dosen maupun soal-soal yang ada di buku pegangan perkuliahan. Perkuliahan hanya didominasi dosen sedangkan mahasiswa hanya menunggu penjelasan dari dosen. Sementara dosen sebagai pengajar/pengampu mata kuliah juga akan mengalami kesulitan dalam menyajikan materi kuliah karena selain dibatasi waktu, dosen harus mengulang kembali konsep-konsep kalkulus dasar.

Seorang pengajar/dosen yang baik akan selalu mengevaluasi kualitas kegiatan pembelajaran yang telah dilakukan. Jika terdapat hasil yang kurang bagus (underachievement) maka akan dicoba dengan metode yang lain sehingga kelas yang dibimbing akan selalu berjalan dinamis (Crippen dkk., 2004). Bertolak dari permasalahan tersebut, untuk meningkatkan aktivitas dan hasil belajar mahasiswa diperlukan sebuah pendekatan atau model pengajaran lain.

Salah satu pendekatan pembelajaran yang mampu meningkatkan aktivitas dan hasil belajar adalah metode branistroming. Metode brainstorming merupakan metode yang dapat di gunakan untuk mengaktifkan siswa, siswa di minta memberikan ide atau menyebutkan contoh sebanyakbanyaknya dalam waktu singkat (Nurgayah, 20II). Metode brainstorming sesuai sebagai upaya untuk mengumpulkan pendapat/ide yang dikemukakan oleh seluruh anggota kelompok, baik secara individual maupun kelompok. Metode ini akan menghasilkan berbagai pendapat atau ide dari peserta, baik yang sama (atau saling mendukung) dan ide-ide yang berbeda (atau saling bertentangan). Kedua bentuk ide tersebut dapat memicu terjadinya perdebatan di antara peserta. Metode brainstorming merupakan salah satu teknik untuk memperkirakan sejauh mana pengetahuan (penguasaan materi) yang telah dimiliki peserta (http://file.upi.edu/Direktori/FIP/JUR._PEND._LUAR _SEKOLAH).

Dalam penelitian ini metode branistroming akan digabungkan dengan metode tutor sebaya. Penelitian yang dilakukan oleh Masturi dan Marwoto, menyimpulkan bahwa Pendekatan pendekatan teaching assistant (TA) dapat meningkatkan kualitas perkuliahan (Masturi and P. 
Marwoto, 2010). Griffin dan Carter (2004) menyatakan bahwa keberadaan seorang pemandu pembelajaran (learning assistant) dalam sebuah proses pembelajaran sains dan matematika (eksak) merupakan sesuatu hal yang sangat dibutuhkan. Pemandu tersebut bisa seorang guru, orang tua, ataupun teman, baik teman sejawat maupun teman yang lebih tua yang memiliki kemampuan untuk membantu meningkatkan prestasi belajar mereka (Griffin \& Carter, 2004).

Tujuan penelitian ini adalah meningkatkan aktivitas dan hasil belajar Fisika Matematika I dengan metode Brainstorming dan tutor teman sebaya. Penelitian ini diharapkan memiliki manfaat, pertama, aktivitas belajar mahasiswa akan meningkat. Kedua, dosen akan sangat terbantu dalam melakukan kegiatan perkuliahan kepada mahasiswa sehingga mutu perkuliahan secara umum akan semakin meningkat mengingat mata kuliah ini banyak digunakan sebagai penunjang mata kuliah lain. Ketiga, meningkatnya meningkatnya indeks prestasi belajar.

\section{Metode Penelitian}

Penelitian ini merupakan Penelitian Tindakan Kelas (PTK) dilaksanakan berlangsung pada bulan SeptemberNovember 2012. Dengan subyek penelitian mahasiswa semester III Program studi pendidikan Fisika Universitas Muhammadiyah Purworeo yang berjumlah 6I orang. Teknik Pengumpulan Data yaitu dengan Metode Observasi (untuk mengetahui aktivitas dalam prosess pembelajaran) dan Metode Tes untuk memperoleh gambaran hasil belajar mahasiswa pada setiap siklus.

Tabel I. Kisi-kisi lembar Observasi Aktivitas Belajar

\begin{tabular}{llc}
\hline $\begin{array}{c}\text { Aspek } \\
\text { Aktivitas }\end{array}$ & \multicolumn{1}{c}{ Indikator } & $\begin{array}{c}\text { Banyak Butir } \\
\text { soal }\end{array}$ \\
\hline Visual & a. Tertarik membaca buku pegangan & 3 \\
& b. Sikap ketika dihadapkan dengan & \\
& soal & \\
Emosional & c. Kemampuan dalam mengerjakan & 3 \\
& a. Minat belajar & \\
& b. Semangat mengikuti perkuliahan & \\
Lisan & c. Berusaha memahami materi kuliah & 3 \\
& a. Bertanya kepada dosen & \\
& b. Menyampaikan pendapat atau & \\
Menulis & analisisnya & \\
& c. Berdiskusi & \\
& a. Mencatat hal-hal penting dalam & \\
& b. Menguliahan & \\
\hline
\end{tabular}

Teknik Analisis data yang digunakan pada penelitian ini adalah secara kuantitatif atau membandingkan data yang diperoleh sebelum dilakukan tindakan dan sesudah dilakukan tindakan. ntuk mengukur tingkat persentase data sebelum tindakan, siklus I dan siklus II digunakan rumus:

$$
N P=\frac{R}{S M} x 100 \%
$$

$N P=$ Nilai persen yang dicari atau diharapkan, $R=$ Skor mentah yang diperoleh, $S M=$ Skor maksimum dari test yang bersangkutan (Purwanto, 2002).

Penelitian ini dilakukan dengan menggunakan desain Penelitian Tindakan Kelas (PTK). Adapun skematis model PTK sesuai dengan Gambar I.

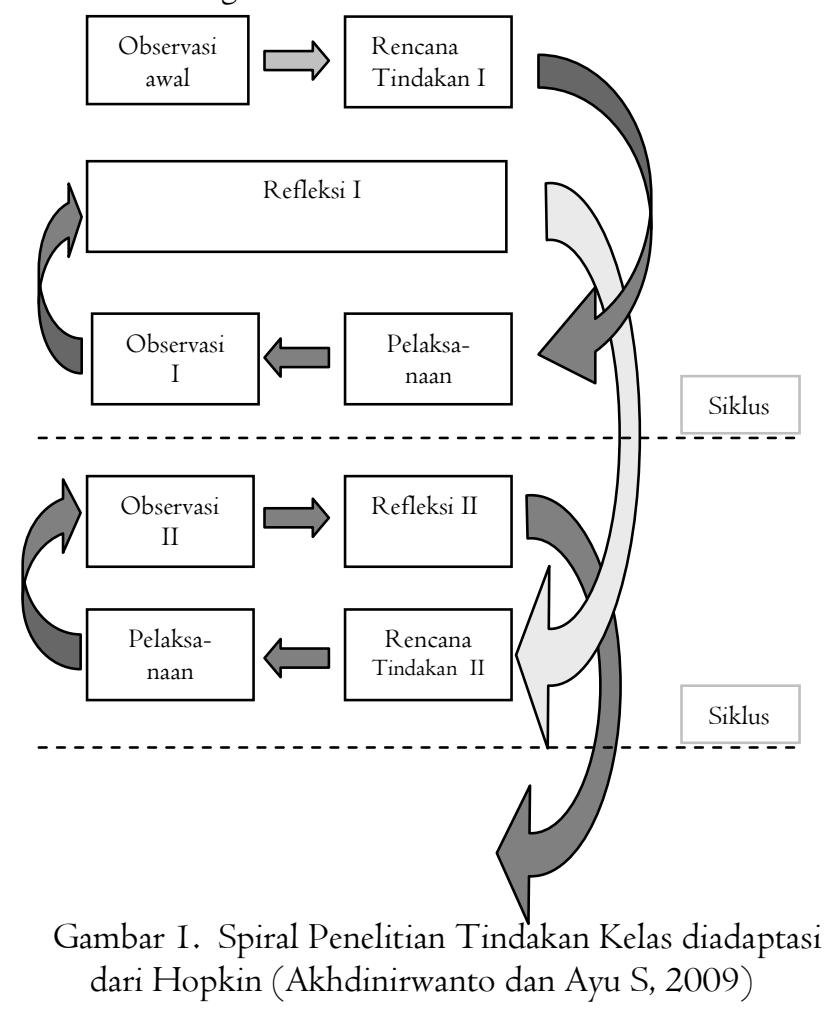

\section{Pembahasan}

Analisis data dilakukan untuk mengetahui data yang diperoleh menujukkan peningkatan aktivitas dan hasil belajar selama proses pembelajaran dengan metode Brainstorming dan Tutor teman sebaya.

Lembar observasi digunakan untuk mengetahui aktivitas belajar selama proses pembelajaran berlangsung. Observasi yang dilakukan oleh peneliti yaitu proses pembelajaran sebelum penerapan metode Brainstorming dan Tutor teman sebaya dilakukan selama satu minggu untuk mengetahui aktivitas belajar prasiklus. Selanjutnya observasi pada siklus I dan II dengan jalan memberikan cheklist pada 
instrumen yang telah disiapkan. Berdasarkan penyajian data di atas maka skor yang diperoleh pada masing-masing siklus dapat disajikan dalam diagram batang sesuai dengan gambar 2.

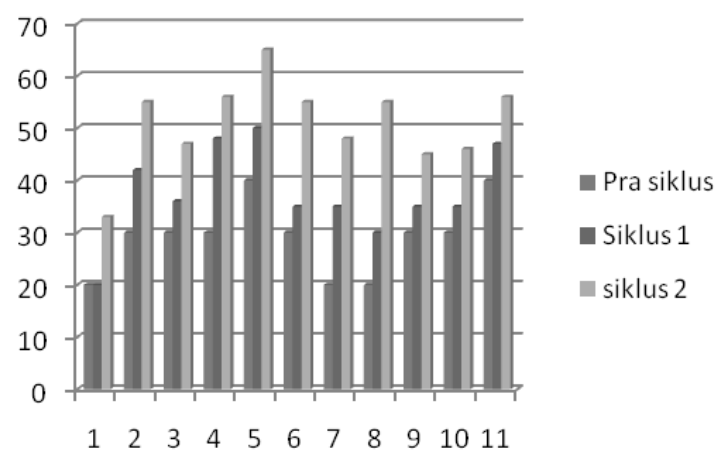

Gambar 2. Grafik perbandingan aktivitas belajar prasiklus, Siklus I dan Siklus 2

Dari observasi didapatkan bahwa aktivitas belajar mahasiswa juga cukup memuaskan yang terlihat dari meningkatnya jumlah mahasiswa yang bertanya dan semangat ketika mengerjakan soal. Namun setelah dilakukan tes I, ternyata pencapaiannya hasil belajar masih belum memuaskan. Hal ini terlihatpada distribusi nilai mahasiswa yang disajikan pada gambar 3. Dari gambar 3 didapatkan bahwa nilai rata-rata kelas yang diperoleh pada siklus I adalah 58,7 (C-). Dalam tindakan ini, nilai C ditetapkan sebaga ibatasan nilai minimal seorang mahasiswa sudah mencapai ketuntasan belajar. Dengan demikian, dalam siklus I secara rata-rata mahasiswa belum mencapai ketuntasan belajar.

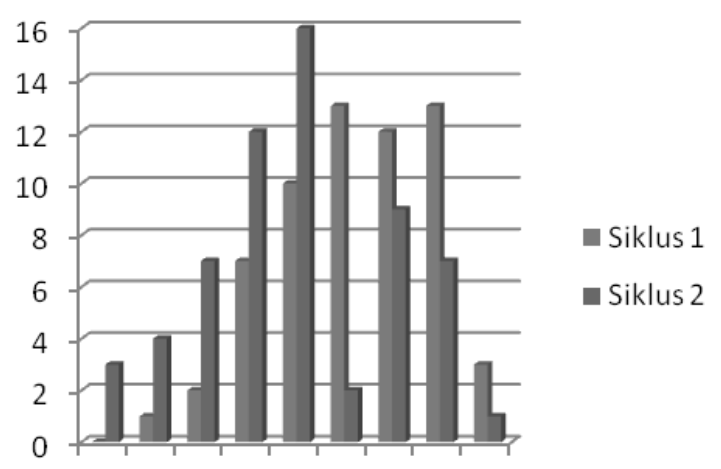

$A \quad A-B+B$ B $-C+C$ C $-D$

Gambar 3. Grafik distribusi nilai pada siklus I dan siklus II

Hasil refleksi pada siklus I didapatkan beberapa kelemahan. Salah satu di antaranya adalah belum paham metode brainstorming dan belum maksimalnya peran tutor.
Mahasiswa masih sulit untuk diajak kerjasama mengemukakan kesulitan-kesulitannya. Untuk mengatasi itu peneliti mencoba mengacak kembali kelompok berdasarkan hasil tes siklus I.

Di siklus 2 didapatkan bahwa aktivitas belajar secara umum mengalami peningkatan pada semua indikator dibanding silkus I. Pada akhir siklus 2 dilakukan evaluasi dan didapatkan nilai rata-rata kelas pada siklus 2 mengalami peningkatan menjadi 65,4 (B-), artinya rata-rata mahasiswa telah mendapatkan pemahaman yang cukup baik (B-) atas materi-materi pada perkuliahan fisika matematika I.

\section{Kesimpulan}

Dari penelitian ini dapat disimpulkan bahwa dengan metode Brainstorming dan tutor teman sebaya dapat meningkatkan aktivitas dan hasil belajar Fisika Matematika I. Dari siklus I dan siklus 2 teramati adanya peningkatan Aktivitas belajar yakni dari $37,54 \%$ menjadi $51 \%$ dan peningkatan hasil belajar yakni dari 58,7 (C-) menjadi 65,4 (B-)

\section{Kepustakaan}

Crippen, K.J., Archambault, L., Ford, M.S., \& Levitt, G.A. Curriculum Carts and Collaboration: A Model for Training Secondary Science Teachers. Journal of Sciences dan Education Technology. 2004. 13: 325 $33 \mathrm{I}$

Griffin, A.R., \& Carter, G. Technology as a Tool: Applying an Instruc-tional Model to Teach Middle School Students to Use Technology as a Mediator of Learning. Journal of Science Education and Technology. 2004. I3: $495-504$

Masturi and P. Marwoto, Jurnal Pendidikan Fisika Indonesia 6. Peningkatan Kualitas Perkuliahan Solusi Deret Melalui Pendekatan Teaching Asistant. 2010. 2025

R. Wakhid Akhdinirwanto dan Ida Ayu S. Cara Mudah Mengembangkan Profesi Guru. Yogyakarta: Sabda Media. 2009

Ngalim Purwanto. Prinsip-Prinsip dan Tehnik Evaluasi Pengajaran. Bandung: Remaja Rosdakarya. 2002

Nurgayah. Strategi \& Metode Pembelajaran. Bandung Ciptapustaka. 20I I.

http://file.upi.edu/Direktori/FIP/JUR._PEND._LUAR _SEKOLAH/ 